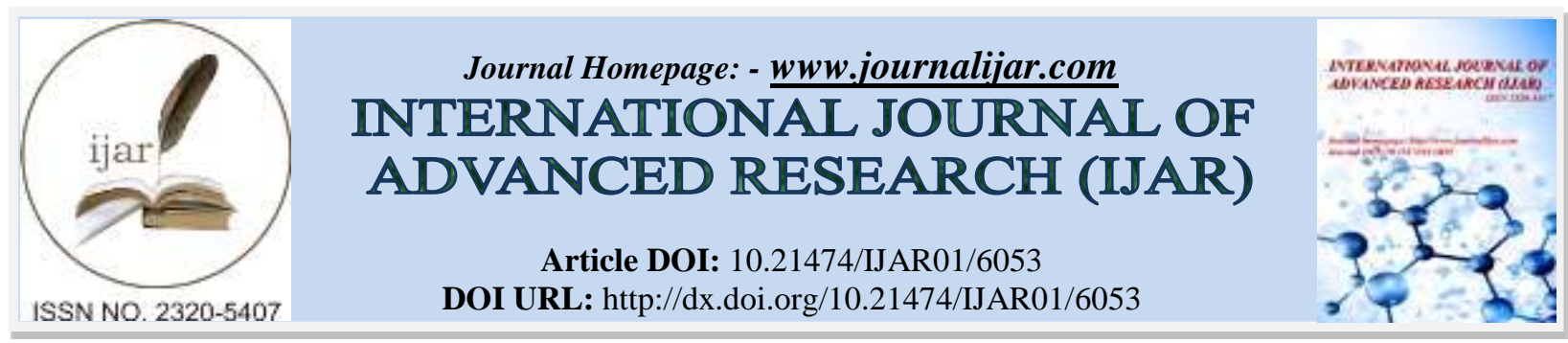

RESEARCH ARTICLE

\title{
COLORECTAL CANCER IN MARRAKECH TENSIFT ELHAOUZ, EPIDEMIOLOGICAL AND ANATOMOPATHOLOGICAL ASPECTS, ABOUT 2584 CASES IN 19 YEARS.
}

\author{
Khalid Rabbani, Jihane Hakam, Youssef Narjis, Redouane Benelkhaiat, Abdelouahed Louzi, Hamid El \\ Idrissi Dafali and Abdenasser Finech. \\ Surgical department of Mohamed VI University hospital, Marrakech, Morocco.
}

\section{Manuscript Info}

Manuscript History

Received: 14 October 2017

Final Accepted: 16 November 2017

Published: December 2017

Key words:-

Adenocarcinoma, Colon, Rectum, Marrakech.

\begin{abstract}
Up to the 20th century, colorectal cancer used to be quite scarce and its incidence has increased at the same rate as the economic development. Currently it is considered amongst the most frequent and the most acute malignant tumors. In Morocco, that cancer remains underestimated because of the lack of screening and the delayed diagnosis. We have made this study to evaluate the different epidemiological as much as the anatomopathological aspects of colorectal cancer in Marrakech.

This is a retrospective descriptive study of the different cases of colorectal cancer collected in Marrakech between 1997 and 2015.

We could identify 2584 cases of colorectal cancer, $44 \%$ of whom have colonic cancer and $56 \%$ with rectal cancer. The male gender is predominant with a ratio of 1.34 . The mean age in our series was 55.4 years with extreme ages ranging from 18 to 100 years. Polyps and adenomas were the major risk factor in the development of colorectal cancer. The sigmoid colon represented $44 \%$ of the different localizations of colon cancer while the lower rectum was the site of predilection of the rectal affections with $32 \%$ of the cases. The Lieberkunien adenocarcinoma was distinguished from other histological forms with $87 \%$ of all cases of colorectal cancer followed by the mucinous form.

From these results, rises the need for the development of screening and prevention strategies at regional and especially national levels based on data from a cancer registry. This is the starting point of a mass movement aiming to improve the patients' access to health care and to medical support.
\end{abstract}

Copy Right, IJAR, 2017, All rights reserved.

\section{Introduction:-}

Colorectal cancer constitutes, by its frequency and severity, a major health problem. It is ranged third cancer in the world after lung and breast cancer. Nearly one million colorectal cancers are diagnosed, and nearly half a million people die each year [1]. Despite the tangible progress made in the recent decades in the field of diagnostic explorations, its frequency remains underestimated and mortality high [2]. Its incidence varies from one country to another due to the differences in people's way of life, type of diet and hereditary predisposition. However, a common finding is that we are beginning to notice a rejuvenation of the population with this type of cancer [3]. 
Adenocarcinoma is the most common histological type. Second, there are other varieties such as lymphomas, carcinoid tumors and other much rarer histological types [4]. Epidemiological data in this context have long been unknown in Morocco but now it is starting to develop thanks to the introduction of cancer registries. In this sense rised the need to carry out a descriptive epidemiological study in order to establish the state of the art of colon cancer and rectal cancer in Marrakech Tensift region. This is an essential step upstream of any colorectal tumor screening strategy.

\section{Material and methods:-}

We conducted a descriptive retrospective study over a period of 19 years from January 1 st, 1997 to December 31 st, 2015. We collected all histologically confirmed cases of colonical and rectal cancer that were collected in the records of pathology laboratories in the Marrakech region and covering the period of our study.

\section{Results:-}

We collected 2584 cases of colorectal cancer including 1453 cases of rectal cancer (56.2\%) and 1131 cases of colonic cancer (43.8\%). The number of cases has increased over the years from about 50 cases in 1997 to 398 cases in 2015. The average age in our series was 55.4 years with extremes ranging from 18 to 100 years. The sex ratio was 1.34. The results for the different locations were as follows: For colonical cancer: The average age was 55 with extremes ranging from 19 to 85 years. The male sex was predominant with $53 \%$ of the cases leading to a sex ration of 1.34. Precancerous conditions were noted in 248 patients, the polyp and tubule adenoma accounted for $45 \%$ of the cases collected. In the majority of cases, the cancer was developed in the sigmoid colon (43.7\%), followed by the ascending colon $(23 \%)$ and then the left colon (20\% of the cases). Rarer localizations were diagnosed as right and left colic angles as well as transverse colon (3\% of cases). In the anatomopathology study, several macroscopic aspects were found but with a clear predominance of the ulceroburging form (47\% of cases) followed by the infiltrated form (23\% of cases). Colon cancer was revealed by an occlusive syndrome in $6 \%$ of cases. In most of cases, colon cancer was moderately differentiated Lieberkunian adenocarcinoma (87\% of cases).

Concerning the rectal cancer, the average age was 54 years old with extremes ranging from 18 to 100 years old. The male sex was predominant with $59 \%$ of the cases compared to the female sex that represented only $41 \%$ of the cases, which leads to a sex ratio of 1.64 . The risk factors were only specified on 430 of the cases. The cancer was developed in the most of the cases (53\% of the cases) from tubular and tubulovillous adenomas. However, the polyp have participated in $36 \%$ of the cases in the development of the rectal cancer. The lower rectum was the preferred seat for the development of this type of cancer with a rate of $32 \%$ followed by the middle and upper rectum. In our series, rectal cancer was most often ulceroburging ( $54.4 \%$ of cases), in $85 \%$ of cases a lieberkunien adenocarcinoma and in the most of the cases well differentiated (47.1\% of cases).

\section{Discussion:-}

Colorectal cancer is considered the second leading cancer in terms of worldwide incidence (approximately 1.234,000 cases worldwide according to GLOBOCAN in 2008 and 342,137 cases in 27 European countries in 2012) [5] and the fourth cancer responsible for global mortality (149,984 deaths in Europe) [6,7]. In the United States, colorectal cancer ranks third among all cancers and the second most deadly cancer [8]. Various studies have shown that in Canada, Australia, New Zealand and most of the European countries, the incidence and mortality of colorectal cancer has decreased since the 1970s; This would have been explained by the decrease in exposure to different risk factors, early detection and better management [9-14]. Nevertheless, for some of these countries that have undergone a demographic transition such as Central America, South America and Eastern Europe, the incidence of colorectal cancer has reportedly increased [10-17]. In France, with 38,000 new cases per year, colorectal cancer is the third most common cancer behind prostatic and breast cancer, accounting for $10 \%$ of all cancers [18]. In 20 years, the incidence has increased by 40\% [19-21]. This has also been observed in Sweden [22]. In Algeria, it accounts for $7.8 \%$ of all cancers and comes in the second place [23]. In Morocco, given the paucity of epidemiological studies in this direction and cancer registries, only a few studies have allowed a rough analysis of the state of the art in colorectal cancer. Thus the register of digestive cancers of Casablanca has placed colorectal cancer in second place in men and pole position in women after stomach cancer [24]. According to Pr. Guerbaoui's study, colorectal cancer ranks third among all cancers (3.3\%) [25]. According to the Al Azhar Oncology Center in Rabat, the number of cases collected was 433 new cases over a period from 1994 to 2004 and represents $49.6 \%$ of all new cases of digestive cancers described during this period [26]. Concerning Fès, a study carried out by the department of anatomic pathology on digestive cancers at the university hospital of Hassan II in Fès between 2004 
and 2007, counted 432 cases of digestive cancers, representing 18.5\% of the population. Among all cancers, colorectal cancer ranked first with 166 cases [27]. Several series around the world have demonstrated a slight male predominance with a sex ratio of 1.5 [28]. The incidence is the same in both sexes up to the age of 65, then there is a predominance in males, secondary to a higher incidence of ascending colon and sigmoid cancers [29]. From a study done in America and which included several states, we note that for some countries like Cuba the number of cases does not exceed the thousand in 3 years. However, in Brazil, this number is seen multiplied by 10. The female sex was especially important for colonic localization, however men were diagnosed with many more rectal cancers. This was explained as for some American countries such as Brazil and Argentina, by the fact that they made available screening protocols ranging from a digital rectal examination to the completion of a colonoscopy at the slightest doubt [30]. Tunisia also joins the same statistics with a clear predominance of women [31]. Colorectal cancer is rare before the age of 50 where it represents only $6 \%$ [28]. The incidence then increases rapidly with age. The average age at diagnosis is 69.5 years for men and 72.8 years for women [29]. According to data from digestive tumor registries in France, the proportion of colorectal cancers occurring among persons aged 75 and over increased from $38.4 \%$ for the period 1976-1979 to $45.2 \%$ for the period 1992-1995. Recently in 2016 a large scale study was carried out. The histological data and samples that were collected were from 11 international studies where the mean age was 66 (21-98) with 55\% male participation [32]. In Tunisia, in a case-control study involving 100 patients, the age extremes ranged from 28 years to a maximum of 90 years averaging 57.5. The most representative age group was 40 to 69 years of age with $26 \%$ of cases of rectal cancer and $40 \%$ of cases of colon cancer [31]. In Morocco, the studies concluded, as demonstrated by the study of the Al Azhar Oncology Center in Rabat, that the average age of patients diagnosed with colorectal cancer was 54.2 years $(7.7 \%$ of patients were under 35 years of age, $81.3 \%$ were between 35 and 69 years old and $11 \%$ of the patients were older than 70 years) [26]. The study of the incidence of colorectal cancer in people under 40 years in different series has demonstrated a rejuvenation of the population suffering from this type of cancer, probably explained by the change in lifestyle and diet populations. Thus, there is a high incidence in Saudi Arabia with 21 to $23 \%$ of cases, Italy with 17\%, Japan with 10\%. In Western countries this frequency is low $[3,33,34]$. In Morocco the estimations are for $26.6 \%$ of patients who are younger than 40 years of age for rectal cancer [35]. There is no strict parallelism between the incidence rates of colon cancer and those of rectal cancer in high-risk areas. Incidence rates for colon cancer are higher in North America than in Western Europe, while those for rectal cancer tend to be higher in Western Europe. In North America and Australia, reports of colon / rectum incidence rates range from 1.5 to 2.0 for men, and 2.0 to 2.5 for women. The fact that in the different regions the sex ratio of colon cancer on the one hand and rectal cancer on the other hand are identical runs counter to an incriminating explanation of the classification artifacts at the origin. differences in colon / rectum ratios in high-risk countries [36].

Several studies have shown that the distal colon (descending and sigmoid colon) was the most affected, followed by the rectum and lastly the proximal colon (caecum and ascending colon) [37,38]. This is because distal and proximal colorectal lesions have distinct molecular characteristics [39, 40]. All these differences between the two sites are mainly due to the embryonic tissue from which they originate and the lifestyle and habits of individuals [41]. Previous studies have shown that right colon tumors occur most of the time at older ages. The immunological study of proximal tumors is also different from that of the distal colon [42, 43]. In a study conducted in Iran between 2008 and 2013 [44], the anatomical study and distribution of tumors was similar in the left colon (32.6\%) and the right colon (29.5\%). Omranipour et al. conducted a study of 442 patients with CRC of which 157 (35.5\%) were colon cancers and $285(64.5 \%)$ were rectal cancers, and found that $43.3 \%$ of colon cancers were located on the right colon and $56.7 \%$ on the left colon [45]. In contrast, Mahmodlou et al. reported a significant number of tumors located in the right colon (35\% of the cases), followed by the left colon (20\% of the cases) [46].

In France [32], out of 4151 cases of CRC identified in 2016, the left colon was in pole position with $45 \%$ of cases followed by right colon and rectum with respectively $41 \%$ and $14 \%$ of cases. The transverse colon is rarely identified because of the scarcity of this location. It accounts for about $10 \%$ of colorectal cancers. His diagnosis is often made lately. It appears in a complicated form in 30 to $50 \%$ of cases (occlusion, perforation, internal fistula) [19]. Rectal involvement is dominated by the involvement of the lower rectum [47].

The most common histological form of CRC (approximately 96\%) is adenocarcinoma [48].

Once the cancer takes place in the inner lining of the large intestine, it can spread in the thickness of the wall. Thus, it can also penetrate the blood vessels or lymphatics. The cancer cells are usually distributed first to the surrounding lymph nodes. Cancer cells can also spread into the blood vessels of the liver or lungs, the pelvis and the abdominal cavity to other organs and tissues, such as the peritoneum and the ovary. The CRC is generally in the histological 
form of adenocarcinoma. Nevertheless, other histological types exist but are much less common, such as neuroendocrine tumors, lymphomas, sarcomas, and squamous cell carcinomas, which can also be found in the rectum [49-52]. The incidence of each of these forms is difficult to calculate. According to SEER data from 2005 to 2009, out of 183,000 cases of colorectal cancer (excluding lymphomas), $94.3 \%$ were adenocarcinomas, $1.7 \%$ other types of carcinomas, $3.3 \%$ carcinoid tumors, $0.5 \%$ of squamous cell carcinomas, $0.1 \%$ of sarcomas, and $0.1 \%$ of other histological types [4]. Concerning the differentiation, the adenocarcinoma is distinguished in 4 entities according to the richness in glandular tubes, the stroma-reaction and the number of mitosis. Thus it can be well, moderately, poor or undifferentiated, ranging from a better to a less good prognosis [53]. The presence of a colloidal mucosal component proves to be a poor prognosis with the frequency of local recurrences and the reduction of the 5year survival rate to $19 \%$ [54].

Adenocarcinoma is most often well and moderately differentiated. This was faced by the study conducted in Taharan, Iran where the CRC was predominantly well differentiated (43\% of cases), moderately and poorly differentiated in respectively $30.6 \%$ and $19.8 \%$ of cases and undifferentiated in $6.6 \%$. \% of cases [44]. Similar results in a Tunisian study where CRC adenocarcinoma was well differentiated in $46 \%$ of cases, moderately differentiated in $33.3 \%$ of cases and undifferentiated in $11.3 \%$ of cases [55]. Our series and the Moroccan series report the same results $[47,56,57]$.

\section{Conclusion:-}

Colorectal cancer is a public health burden. It is the 2 nd cancer in terms of incidence in the world and the 3 rd cancer in Morocco. The genetic predispositions, the socio-economical level of the countries and the habits of life of the populations lead to heterogeneity in the distribution of this cancer around the world. Colorectal cancer affects men more often than women, most of them aged more than 50. The predominant histological form remains adenocarcinoma. The prognosis of colorectal cancer has significantly improved thanks to screening, early diagnosis and the development of surgical techniques and associated treatments especially with the development of targeted therapies, but it remains unfortunate in our context because of the establishement of the diagnosis at late stages. This study therefore encourages:

1. To awareness of risk factors for colorectal cancer,

2. The development of methods more sensitive to diagnosis,

3. The generalization of colorectal cancer screening,

4. Educational campaigns for the prevention of colorectal cancer,

5. Improving access to care,

6. The encouragement of research in the fields of genetics and targeted therapies,

7. The imperative development of a colorectal cancer registry including data from both the public and private sectors.

This would certainly allow, in a near future, the considerable reduction of the mortality and the morbidity related to this pathology in Morocco.

\section{Conflicts of interest:-}

The authors don't claim to have any conflict of interest.

\section{References:-}

1. T Lecomte, T André, Y Panis, P Laurent-Puig, F Bibeau, J Taieb. «Cancer du côlon». Thésaurus National de Cancérologie Digestive, 11-2016, [En ligne] http://www.tncd.org

2. Grosclaude P, Remontet L, Belot A, Danzon A, Rasamimanana C, Bossard N.

3. Survie des personnes atteintes de cancer en France, 1989-2007 - Etude à partir des registres des cancers du réseau Francim. Saint-Maurice : Institut de veille sanitaire ; 2013. 412 p. [rapport et synthèse]

4. Kabouri K. Cancer colorectal chez le jeune de moins de 40 ans à propos de 110 cas. CHU Ibn Sina, Rabat, 2000.

5. Errasti, A. J., Espín, B. E., \& Reina, D. A. (2014). Rare tumors of the rectum. Narrative review. Cirugia espanola, 92(9), 579-588

6. Van de Velde, C. J., Aristei, C., Boelens, P. G., Beets-Tan, R. G., Blomqvist, L., Borras, J. M., ... \& Espin, E. (2013).

7. EURECCA colorectal: multidisciplinary mission statement on better care for patients with colon and rectal cancer in Europe. European Journal of Cancer, 49(13), 2784-2790. 
8. Ferlay, J., Shin, H. R., Bray, F., Forman, D., Mathers, C., \& Parkin, D. M. (2010).Estimates of worldwide burden of cancer in 2008: GLOBOCAN 2008. International journal of cancer, 127(12), 2893-2917.

9. Ferlay, J., Steliarova-Foucher, E., Lortet-Tieulent, J., Rosso, S., Coebergh, J. W. W., Comber, H., ... \& Bray, F. (2013).

10. Cancer incidence and mortality patterns in Europe: estimates for 40 countries in 2012. European journal of cancer, 49(6), 1374-1403.

11. Samadder, N. J., Curtin, K., Wong, J., Tuohy, T. M., Mineau, G. P., Smith, K. R., ... \& Provenzale, D. (2014).

12. Epidemiology and familial risk of synchronous and metachronous colorectal cancer: a population-based study in Utah. Clinical Gastroenterology and Hepatology, 12(12), 2078-2084.

13. Stewart, B., \& Wild, C. P. (2016). World cancer report 2014. World. 2016

14. Center, M. M., Jemal, A., \& Ward, E. (2009). International trends in colorectal cancer incidence rates. Cancer Epidemiology Biomarkers \& Prevention, 18(6), 1688-1694.

15. Center, M. M., Jemal, A., Smith, R. A., \& Ward, E. (2009). Worldwide variations in colorectal cancer. $C A$ : $a$ cancer journal for clinicians, 59(6), 366-378.

16. Bosetti, C., Malvezzi, M., Chatenoud, L., Negri, E., Levi, F., \& La Vecchia, C. (2005).Trends in cancer mortality in the Americas, 1970-2000. Annals of Oncology, 16(3), 489-511.

17. Jemal, A., Thun, M. J., Ries, L. A., Howe, H. L., Weir, H. K., Center, M. M., ... \& Ajani, U. A. (2008). Annual report to the nation on the status of cancer, 1975-2005, featuring trends in lung cancer, tobacco use, and tobacco control. Journal of the National Cancer Institute, 100(23), 1672-1694.

18. Edwards, B. K., Ward, E., Kohler, B. A., Eheman, C., Zauber, A. G., Anderson, R. N., ... \& van Ballegooijen, M. (2010).

19. Annual report to the nation on the status of cancer, 1975-2006, featuring colorectal cancer trends and impact of interventions (risk factors, screening, and treatment) to reduce future rates. Cancer, 116(3), 544-573.

20. Bray, F., Jemal, A., Grey, N., Ferlay, J., \& Forman, D. (2012).

21. Global cancer transitions according to the Human Development Index (2008-2030): a population-based study. The lancet oncology, 13(8), 790-801.

22. Arnold, M., Sierra, M. S., Laversanne, M., Soerjomataram, I., Jemal, A., \& Bray, F. (2016). Global patterns and trends in colorectal cancer incidence and mortality. Gut, gutjnl-2015.

23. Sierra, M. S., \& Forman, D. (2016). Burden of colorectal cancer in Central and South America. Cancer Epidemiology, 44, S74-S81.

24. Lafay, L., \& Ancellin, R. (2015). Alimentation et cancer colorectal. Cahiers de Nutrition et de Diététique, 50(5), 262-270.

25. Le, P., Mehtari, L., \& Billey, C. (2006). Les tumeurs du colon transverse. Journal de Chirurgie, 143(5), 285293.

26. Belot, A., Velten, M., Grosclaude, P., Bossard, N., Launoy, G., Remontet, L., ... \& Chérié-Challine, L. (2008). Estimation nationale de l'incidence et de la mortalité par cancer en France entre 1980 et 2005 (p. 132 ). Saint-Maurice (France): Institut de veille sanitaire.

27. Kudjawu, Y. C., Eilstein, D., Decool, E., De Maria, F., Beltzer, N., \& Chatellier, G. (2015). Time to first treatment after colonoscopy in patients suffering from colon or rectum cancer in France. Cancer epidemiology, 39(6), 877-884.

28. Birgisson, H., Talbäck, M., Gunnarsson, U., Påhlman, L., \& Glimelius, B. (2005).Improved survival in cancer of the colon and rectum in Sweden. European Journal of Surgical Oncology (EJSO), 31(8), 845-853.

29. Tlemsani. H. Janati. R. Sahib H. Registre des cancers Sétif Algérie 1993-1997. Publication 2004

30. Benider.A., M.Bennani Othmani, M.Katomi, A.Quessar, S.Sahraoui. Registre des cancers de la région grand Casablanca. Année 2004 Edition 2007.

31. Guerbaoui M. Le cancer au Maroc: épidémiologie descriptive de 1950 à 1980. El Jadida: Najah, 1ere edition 2000; 250 p: 119-25

32. Ayoujil A., Hami H., Habib F., Soulaymani A., Mokhtari A., Quyou A. Colorectal cancer in Morocco: a retrospective study. European Journal of Cancer 50, suppl. 1 (2014) S9-S15

33. Amarti A. Thèse : Les cancers digestifs au CHU HASSAN II Fès, Service d'anatomopathologie de Fès 2008

34. Rougier, P. (2004). Cancers du côlon et du rectum. Mieux les dépister et mieux les traiter. La Revue du praticien, 54, 133-142.

35. Viguier, J. , Bourlier, P., Karsenti, D., et al. Cancer du côlon. Encycl méd Chir, Gastro-entérologie, 2003, p. 9068 .

36. Sierra, M. S., \& Forman, D. (2016). Burden of colorectal cancer in Central and South America. Cancer Epidemiology, 44, S74-S81. 
37. Kassab, A., Landolsi, S., Miled, A., Ahmed, S. B., \& Olfa, G. (2013). Existe-t-il une relation entre les habitudes alimentaires en Tunisie et le cancer colorectal? Éléments de réponse à partir d'un échantillon de population. Immuno-analyse \& Biologie Spécialisée, 28(5), 327-334.

38. Dreyer, C., Afchain, P., Trouilloud, I., \& André, T. (2016). Nouvelles classifications moléculaires du cancer colorectal, du cancer du pancréas et du cancer de l'estomac: vers un traitement à la carte ?. Bulletin du Cancer, 103(7), 643-650.

39. Pocard, M., Gallot, D., De rycke, Y., \& Malafosse, M. (1997).Adénocarcinome colorectal chez le sujet de moins de 40 ans. Gastroenterol Clin Biol, 21, 955-9.

40. Kam, M. H., Eu, K. W., Barben, C. P., \& Seow-Choen, F. (2004). Colorectal cancer in the young: a 12-year review of patients 30 years or less. Colorectal disease, 6(3), 191-194

41. Lak K. Thèse : Le cancer du rectum, étude rétrospective de 83 cas au service des urgences chirurgicales viscérales CHU Ibn Rochd, Casablanca, 2006.

42. Doyon C, Sancho-garnier H. Incidence and mortality of colorectal cancer in USA. World J Gastroenterol 2006 January $7 ; 12(1): 17-20$.

43. Menegoz, F., Black, R. J., Arveux, P., Magne, V., Ferlay, J., Buemi, A., ... \& Grosclaude, P. (2000). Cancer incidence and mortality in France in 1975-95. European journal of cancer prevention, 6(5), 442-466.

44. Gao, J. D., Shao, Y. F., \& Shan, Y. (2004). [Clinical analysis of surgery for rectal cancer in 122 elderly patients]. Ai zheng= Aizheng $=$ Chinese journal of cancer, 23(3), 296-298.

45. Bufill, J. A. (2000). Colorectal cancer: evidence for distinct genetic categories based on proximal or distal tumor location. Annals of internal medicine, 113(10), 779-788.

46. Siegel, R. L., Ward, E. M., \& Jemal, A. (2012). Trends in colorectal cancer incidence rates in the United States by tumor location and stage, 1992-2008. Cancer Epidemiology Biomarkers \& Prevention, 21(3), 411-416.

47. Toyomura, K., Yamaguchi, K., Kawamoto, H., Tabata, S., Shimizu, E., Mineshita, M., ... \& Kono, S. (2004). Relation of cigarette smoking and alcohol use to colorectal adenomas by subsite: The self-defense forces health study. Cancer science, 95(1), 72-76.

48. Hansen, I. O., \& Jess, P. (2012). Possible better long-term survival in left versus right-sided colon cancer-a systematic review. Dan Med J, 59(6), A4444-A4444.

49. Derwinger, K., \& Gustavsson, B. (2011). Variations in demography and prognosis by colon cancer location. Anticancer research, 31(6), 2347-2350.

50. Kashfi, S. M. H., Mojarad, E. N., Pourhoseingholi, M. A., Aghdaei, H. A., Anaraki, F., \& Zali, M. R. (2015). Evaluation of the left-to-right shift of colon tumors in Iran: Is the trend changing?. Journal of research in medical sciences: the official journal of Isfahan University of Medical Sciences, 20(10), 978.

51. Omranipour, R., Doroudian, R., \& Mahmoodzadeh, H. (2012). Anatomical distribution of colorectal carcinoma in Iran: a retrospective 15-yr study to evaluate rightward shift. Asian Pacific Journal of Cancer Prevention, 13(1), 279-282.

52. Mahmodlou, R., Mohammadi, P., \& Sepehrvand, N. (2012). Colorectal cancer in northwestern Iran. ISRN gastroenterology, 2012.

53. Bellefqih, S., Khalil, J., Mezouri, I., Lahdiri, I., Nejjar, I., Hassouni, K., ... \& Benjafaar, N. (2012). Cancer du rectum chez le sujet de moins de 40ans. Cancer/Radiothérapie, 16(5), 555

54. Stewart, S. L., Wike, J. M., Kato, I., Lewis, D. R., \& Michaud, F. (2006). A population-based study of colorectal cancer histology in the United States, 1998-2001. Cancer, 107(S5), 1128-1141

55. Cuffy, M., Abir, F., \& Longo, W. E. (2006). Management of less common tumors of the colon, rectum, and anus. Clinical colorectal cancer, 5(5), 327-337.

56. Kang, H., O’Connell, J. B., Leonardi, M. J., Maggard, M. A., McGory, M. L., \& Ko, C. Y. (2007).Rare tumors of the colon and rectum: a national review. International journal of colorectal disease, 22(2), 183-189.

57. Reickert CA. Uncommon colorectal neoplasms. Clin Colon Rectal Surg. 2011;24:127-8.

58. Peralta, E. A. (2009). Rare anorectal neoplasms: gastrointestinal stromal tumor, carcinoid, and lymphoma. Clinics in colon and rectal surgery, 22(02), 107-114.

59. Sedkaoui Ch.Thèse : Chimiothérapie et thérapie ciblée dans le cancer colorectal métastatique. Faculté de médecine Tizi-Ouzou. 2015

60. Hamilton, S. R., Aaltonen, L. A., et al. (ed.). Pathology and genetics of tumours of the digestive system. Lyon: IARC press, 2000.

61. Arfa, N., Hamdani, I., Gharbi, L., Abid, S. B., Ghariani, B., Mannai, S., ... \& Mzabi, S. R. (2006).Survie et facteurs pronostiques des adénocarcinomes colorectaux: étude analytique uni-et multifactorielle de 150 cas. In Annales de chirurgie (Vol. 131, No. 2, pp. 104-111). Elsevier Masson. 
62. Mrini, K., Essamri, O., Benbelbarhdadi, I., Ajana, F. Z., Afifi, R., Benazzouz, M., \& Essaid, A. (2009). (049). Epidemiologic characteristics of rectal cancer: About a Moroccan experience from teaching hospital. Arab Journal of Gastroenterology, 10(2), AB27.

63. Fadlouallah, M., Benzzoubeir, N., Errabih, I., Krami, H., Ahallat, M., Ouazzani, L., \& Ouazzani, H. (2009). (054). Colorectal carcinoma in patients younger than 40years of age: About 40 cases. Arab Journal of Gastroenterology, 10(2), AB29. 